\title{
Tax Preparation Services for Low- and Moderate- Income Households: Preliminary Evidence from a New Survey
}

\author{
Michael S. Barr \\ University of Michigan Law School, msbarr@umich.edu \\ Jane K. Dokko \\ University of Michigan Law School
}

Available at: https://repository.law.umich.edu/articles/1785

Follow this and additional works at: https://repository.law.umich.edu/articles

Part of the Law and Society Commons, Legal Writing and Research Commons, Social Welfare Law Commons, and the Taxation-Federal Commons

\section{Recommended Citation}

Barr, Michael S. "Tax Preparation Services for Low- and Moderate-Income Households: Preliminary Evidence from a New Survey." J.K.Dokko, co-author. In Proceedings: 98th Annual Conference on Taxation, edited by J. Diamond, 255-63. Washington, D.C.: National Tax Association, 2006. 


\title{
TAX PREPARATION SERVICES FOR LOW- AND MODERATE-INCOME HOUSEHOLDS: PRELIMINARY EVIDENCE FROM A NEW SURVEY
}

\author{
Michael S. Barr and Jane K. Dokko, University of Michigan
}

\section{INTRODUCTION}

$\mathrm{R}$ ECENTLY, RESEARCHERS HAVE BEGUN TO examine the financial service patterns of low- and moderate-income households. These behaviors are of interest because high cost financial services, barriers to saving, the lack of insurance, and credit constraints contribute to poverty and other socioeconomic conditions (Barr, 2004; Duflo, 2004; and Bertrand et. al., 2005). Many low- and moderate-income households use alternative financial service (AFS) providers, such as check cashers, for their financial services needs (Dunham, 2001; Barr, 2004; and Seidman et al., 2005). Tax preparation firms are among the important financial service providers in the lives of low-income households. Such firms help households navigate the complicated process of filing their taxes, and many low-income households obtain sizeable tax refunds. At the same time, tax preparation is costly, and many tax preparation firms offer "refund anticipation loans" and similar products that add to the costs and complexity of tax filing.

In this paper, we examine financial service patterns among low- and moderate-income households as these patterns relate to the tax system and the process of filing one's taxes. The federal income tax system provides an interesting and important context to study the financial service patterns of low- and moderate-income households for several reasons. First, an overwhelming majority of low- and moderate-income households file tax returns and are eligible for tax refunds. Given the societal goal of redistributing income to low- and moderate-income households through the tax system, optimal income redistribution policy suggests that policymakers focus on reducing the transaction costs associated with tax filing for low-income households. Second, households who face high transaction costs in filing their taxes often face other types of financial constraints, such as not having a bank account or access to credit. Any policy initiative to lower the transaction costs in filing taxes must also consider low-income households' financial services patterns and their use of AFS providers. Third, many low- and moderate-income house- holds receive a large, lump sum at the time of their tax refund. Tax return filing and refund receipt may be important moments for household decision making regarding saving, and thus for savings policy.

Despite the importance of understanding the tax-filing experiences of low- and moderateincome households, there is little empirical evidence on their experiences. In this paper, we study the tax filing experiences of low- and moderateincome households using preliminary (for reasons explained below) data from a unique household survey. We characterize three aspects of households' tax filing experiences. First, we document the prevalence of the use of tax preparation services and the receipt of both tax refunds and refund anticipation loans (RALs). Second, we examine the relationships among bank account ownership, receipt of the Earned Income Tax Credit (EITC), and the use of tax preparation services and RALs. Third, we describe the reasons taxpayers cite for taking out RALs and the uses to which they put their tax refunds. Based on this data, in our conclusion we suggest policy implications and present early conjectures about taxpayer preference parameters; we explore these conjectures in subsequent work.

We present this preliminary evidence on lowand moderate-income households' tax filing experiences in order to inform the policy debate over tax complexity (Holtzblatt and McCubbin, 2004; Barr, 2004; and President's Advisory Panel on Federal Tax Reform, 2005). In addition, we begin to assess whether the ways in which households use paid tax preparers can be viewed as decisions made by rational, optimizing agents, and whether default rules, framing, and heuristics play a role in their tax-filing decisions (Thaler, 1990).

The remainder of this paper is organized as follows. The second section presents the policy context and previous research regarding tax preparation services for low- and moderate-income households. The third section discusses the survey, sampling scheme, and data. The fourth section presents our preliminary results. The fifth section concludes with policy implications. 


\section{POLICY CONTEXT AND PREVIOUS RESEARCH}

The U.S. tax code has numerous provisions that redistribute income to low- and moderate-income households. The Earned Income Tax Credit (EITC) is among the largest federal redistributive tax policies (Eissa and Liebman, 1995). IRS data suggest that more than two-thirds of EITC recipients use paid tax preparers to file their returns, and one study has suggested that one-half of EITC dollars are delivered through RALs and other high-cost means of receiving tax refunds (Berube et al., 2002). Around 8.5 million low-income households (those earning less than $\$ 25,000$ per year) do not have either a savings or checking account (Aizcorbe et al., 2003). Taken together, the EITC and a lack of attachment to the formal financial services sector pose an atypical set of constraints and needs for low- and moderate-income households as they file their taxes.

Many factors contribute to low- and moderateincome taxpayers' use of tax preparation services, including RALs. Low- and moderate-income households may use tax preparation services because of the difficulties in interpreting the tax code and applying it to their complicated lives. These households often face conflicting and complex rules under different tax provisions for determining household status and dependents. They also worry about increased IRS audits and other enforcement measures for EITC filers, along with IRS delays in receiving their refunds (Holtzblatt and McCubbin, 2004). EITC claimants and non-claimants may face different choices with respect to the use of these tax preparation and refund loan services.

Within the group of low-and moderate-income tax filers, banked and unbanked households are also likely to differ in their tax preparation experiences. For example, unbanked tax filers need to wait much longer for their tax refunds because they cannot receive direct deposit of the refund. Unbanked tax filers also need to use AFS providers to cash their refund check. They are also more likely to face higher costs or more difficulties in obtaining access to credit than their banked counterparts.

The first aim of this paper is to characterize the tax preparation choices of low- and moderate-income households, EITC claimants and non-claimants, as well as banked and unbanked households. We document the prevalence of the use of paid tax preparation services, the extent to which households take out RALs, and the cost of tax preparation and RALs. We examine these trends by EITC claimant and banked status, with the hope of beginning to identify the particular constraints that are important in households' decisions to use commercial tax preparers or to take out a RAL.

Tax preparation services need not merely pose financial costs for low-and moderate-income households. Instead, commercial tax preparers may expand the take-up rate for EITC and other tax credits designed to redistribute income to households. Moreover, commercial tax preparers can serve as a vehicle through which to encourage retirement savings (Duflo et. al., 2005). In addition, tax filing and refund receipt may also encourage other types of saving. Research has noted the importance of mental accounts in influencing households' marginal propensities to consume (MPC) income, with a smaller MPC the larger the tax refund (Thaler and Loewenstein, 1989; Thaler, 1990; and Souleles, 1999). As a large lump-sum payment, EITC and related tax refunds could present a saving opportunity for low- and moderate-income households that they may not otherwise have (Souleles, 1999; Barr, 2004; Tufano et al., 2005; Duflo et al., 2005; and Rhine, 2005).

The second aim of this paper is to provide data that could be used to assess the extent to which the IRS and the federal government can positively reform low- and moderate-income households' tax preparation experiences. Currently, the IRS is moving toward permitting taxpayers to split their refunds into more than one direct deposit. Accordingly, taxpayers could choose to use a portion of their refund for long-term saving, such as in a retirement account, provide for a portion of the refund to be deposited into a bank account for short-term saving, or direct a portion of the refund to a paid preparer to pay for tax preparation services. We provide evidence on what tax filers did with their refunds and the reasons households cite for taking out a RAL.

\section{DESCRIPTION OF SURVEY, SAMPLING, AND DATA}

The data for this paper are from a survey we designed. which was administered by the Survey Research Center (SRC) at the University of Michigan. The survey focuses on low- and moderateincome individuals' experiences with formal and informal financial institutions, in addition to their socioeconomic characteristics. Because there is no such comprehensive survey about the financial 
services experiences and attitudes of low- and moderate-income households, the questionnaire required extensive development, pretesting, and validation. The final survey was programmed for computer-assisted, in-person interviewing. The final survey instrument is, on average, 76 minutes in length.

The sample members were selected based on a stratified random sample of the Detroit metropolitan area (Wayne, Oakland, and Macomb counties). We drew sample members from census tracts with median incomes that are $0-60$ percent ("low"), 61-80 percent ("moderate"), and $81-120$ percent ("middle") of the Detroit area's median income of $\$ 49,057$. The sample frame includes more census tracts from the low- and moderate-income strata than the middle one. Hence sample members are more likely to be drawn from the low- and moderate-income strata. Stratum definitions do not, however, restrict the income levels of the sample members to fall within these ranges.'

We completed data collection in March 2006, as this Proceedings volume was going to press. We completed 1,003 interviews and attained a 65 percent response rate. In order to report our results in a timely manner, this paper is based on provisional data drawn from census tracts with $0-60$ percent or 61-80 percent of the Detroit area's median income. We restrict our sample to respondents from these income strata because our preliminary dataset does not yet include sampling weights. By focusing our analysis on the low- and moderate-income strata, our results are representative of respondents living in low- and moderate-income census tracts in the Detroit area. Because the results we present here are provisional, data from this paper should not be cited without the express written permission of the authors.

In this paper, we present provisional results from the tax module of the survey, which consists of 21 questions, some with multiple parts. These questions pertain to experiences the respondent had in tax filing. This means that we do not necessarily capture all of the experiences of the household. We opted to ask the respondent about her own tax experiences, as opposed to the households'. due to data quality concerns. Respondents who did not file a return would probably not be able to recall survey items, like whether the household filed for the EITC or the size of their tax refund. We do not expect many discrepancies between the households' and the individuals' tax experi- ences since the vast majority of respondents file a tax return.

\section{RESULTS}

Table 1 presents a set of descriptive characteristics of our low- and moderate-income sample members. Overall, they have the average characteristics of low- and moderate-income households in the Detroit metropolitan area. They comprise a socioeconomically disadvantaged group relative to the average American household. The sample is predominantly African-American, two-thirds female, and unlikely to be married. Roughly one-third of households have less than a high school diploma or GED, and 30 percent were not employed at the time of the interview. The median household income of the sample is $\$ 20,000$, which is lower than the Detroit metropolitan area's median of $\$ 49,057$ and the national median of $\$ 44,684$. Nearly 40 percent of households lived below the poverty line in 2004. Almost 30 percent do not have a bank account.

Banked and unbanked households differ in their socioeconomic characteristics. Unbanked households are much more likely to be single and never married, and are more likely to be AfricanAmerican. Unbanked households are also more likely than their banked counterparts to be economically disadvantaged. They are less likely to have a high school education or its equivalent. Their median household income of $\$ 10,000$ is less than one-half the median income of banked households. With nearly 60 percent of unbanked households living in poverty, unbanked households are nearly 30 percentage points more likely to have lived below the poverty line than banked households in 2004.

Table 2 documents the tax filing experiences of our sample. While about 70 percent of the sample filed a tax return in the last two years, the tax filing experiences of our respondents reflect their socioeconomic disadvantages. Eighty percent of tax filers received a refund, and the average refund size was a little under $\$ 1,900$ among those receiving a refund. Approximately 37 percent of tax filers apply for the EITC, and 30 percent of them receive it.

Our data confirm national results that find a large portion of low- and moderate-income taxpayers use paid preparers. In our study, 66 percent of low- and moderate-income tax filers used a paid preparer to file their returns. About 37 percent of taxpayers 
Table 1

Mean Characteristics of Survey Sample by Banked Status (Standard Errors in Parentheses)

\begin{tabular}{|c|c|c|c|}
\hline Characteristic & All & Banked & Unbanked \\
\hline Black & $71 \%$ & $68 \%$ & $80 \%$ \\
\hline White & 17 & 19 & 12 \\
\hline Arab & 2 & 3 & 1 \\
\hline Other & 9 & 10 & 7 \\
\hline Female & $66 \%$ & $65 \%$ & $67 \%$ \\
\hline Less than HS Diploma & $31 \%$ & $27 \%$ & $40 \%$ \\
\hline HS Diploma or GED & 23 & 19 & 32 \\
\hline Greater than HS Diploma & 46 & 54 & 28 \\
\hline Age & $44(.54)$ & $45(.66)$ & $40(.90)$ \\
\hline Born in the United States & $92 \%$ & $90 \%$ & $96 \%$ \\
\hline Single/Never Married & $47 \%$ & $40 \%$ & $63 \%$ \\
\hline $\begin{array}{l}\text { Married and } \\
\text { Living with Spouse }\end{array}$ & 18 & 22 & 9 \\
\hline Living with Partner & 4 & 4 & 6 \\
\hline Separated/Widowed/Divorced & 31 & 34 & 22 \\
\hline Household Has No Children & $67 \%$ & $70 \%$ & $60 \%$ \\
\hline Currently Employed & $52 \%$ & $56 \%$ & $40 \%$ \\
\hline Not in Labor Force & 18 & 18 & 17 \\
\hline Currently Non-employed & 31 & 25 & 43 \\
\hline $\begin{array}{l}\text { Participates Often in } \\
\text { Financial Decisions }\end{array}$ & $76 \%$ & $79 \%$ & $69 \%$ \\
\hline Respondents' Monthly Earnings & $1247(133)$ & $1585(185)$ & $434(52)$ \\
\hline Total HH Monthly Income & 1918 (188) & $2331(252)$ & 925 (197) \\
\hline Annual HH Income in 2004 & $29,209(1139)$ & $33,678(1399)$ & $18,407(1247)$ \\
\hline Median HH Income in 2004 & 20,000 & 25,000 & 11,366 \\
\hline$\%$ Below the Poverty Line & $36 \%$ & $28 \%$ & $55 \%$ \\
\hline Sample Size & 927 & 660 & 267 \\
\hline
\end{tabular}

Source: Detroit Area Household Financial Survey.

Notes: Not in labor force includes respondents who said they were retired, homemakers, students, did not have the required documentation, or chose not to work. Non-employed is the percentage of people currently unemployed who are in the labor market. Poverty guidelines come from the Department of Health and Human Services, obtained from http://aspe.hhs,gov/poverty/04poverty.shtml. Respondents are banked if they responded yes to having a checking account, a savings account, an account with a debit card but no checks, or any other account held at a bank, savings and loan, or credit union. Unbanked respondents responded no to having any of these types of accounts.

using a paid preparer took out a RAL or "fast refund" product, which translates to 24 percent of all tax filers or 30 percent of all taxpayers receiving a tax refund. Tax preparation services are costly relative to income and refund size among this sample of low- and moderate-income respondents. On average, RAL users of paid prepares paid $\$ 170$ for tax preparation and RAL services, which represents 7 percent of the average refund of such households
(\$2,319). Among non-RAL users of paid preparers, the cost of tax preparation alone is $\$ 110$, which represents 8 percent of the average refund of these households $(\$ 1,372){ }^{2}$

Banked and unbanked individuals have somewhat different tax filing experiences. Though paid tax preparation services are almost equally likely to be used by both banked and unbanked individuals, the latter group is about 20 percentage points 
TABLE 2

Average Tax Filing Experiences of Banked, Unbanked, EITC Filers, and Non-Filers (Standard Errors in Parentheses)

\begin{tabular}{|c|c|c|c|c|c|}
\hline Characteristic & All & Banked & Unbanked & $\begin{array}{l}\text { Filed for } \\
\text { EITC }\end{array}$ & No EITC \\
\hline $\begin{array}{l}\text { Filed a Tax Return in } \\
2003 \text { or } 2004\end{array}$ & $69 \%$ & $75 \%$ & $54 \%$ & $100 \%$ & $59 \%$ \\
\hline $\begin{array}{l}\text { Received a Refund' } \\
\text { Amount of Federal Refund }\end{array}$ & $\begin{array}{c}80 \% \\
1888(102)\end{array}$ & $\begin{array}{c}80 \% \\
1905(125)\end{array}$ & $\begin{array}{c}81 \% \\
1832(141)\end{array}$ & $\begin{array}{c}89 \% \\
2538(133)\end{array}$ & $\begin{array}{c}75 \% \\
1441(140)\end{array}$ \\
\hline Filed for EITC & $37 \%$ & $34 \%$ & $46 \%$ & --- & --- \\
\hline Received EITC & $30 \%$ & $26 \%$ & $40 \%$ & $\cdots$ & $\cdots$ \\
\hline Used Paid Tax Preparer & $66 \%$ & $66 \%$ & $66 \%$ & $80 \%$ & $58 \%$ \\
\hline Filed by Mail & 11 & 12 & 7 & 3 & 15 \\
\hline Filed by Computer/Phone & 7 & 8 & 2 & 5 & 8 \\
\hline Used Free Service to File & 4 & 3 & 8 & 3 & 5 \\
\hline Got Help from a Friend & 5 & 4 & 11 & 4 & 6 \\
\hline Other & 7 & 7 & 6 & 5 & 8 \\
\hline \multicolumn{6}{|l|}{ Type of Paid Tax Preparer Used ${ }^{2}$} \\
\hline National Chain & $44 \%$ & $40 \%$ & $60 \%$ & $59 \%$ & $32 \%$ \\
\hline Local Firm & 24 & 26 & 18 & $17 \%$ & $30 \%$ \\
\hline Accounting Firm & 16 & 17 & 10 & $12 \%$ & $19 \%$ \\
\hline Other & 16 & 17 & 13 & $13 \%$ & $18 \%$ \\
\hline Received $\mathrm{RAL}^{3}$ & $37 \%$ & $30 \%$ & $62 \%$ & $56 \%$ & $22 \%$ \\
\hline Cost of Tax Preparation with RAL & $169(9)$ & $162(12)$ & $181(14)$ & $185(12)$ & $131(14)$ \\
\hline Cost of Tax Preparation & $109(7)$ & $109(7)$ & $107(19)$ & $147(14)$ & $91(7)$ \\
\hline Sample Size & 927 & 660 & 267 & 236 & 691 \\
\hline \multicolumn{6}{|c|}{ Source: Detroit Area Household Financial Survey. } \\
\hline \multicolumn{6}{|c|}{ 'Percentages are based on those who have filed a tax return. } \\
\hline \multicolumn{6}{|c|}{${ }^{2}$ Percentages are based on the sample of respondents using paid tax preparers. } \\
\hline \multirow{2}{*}{\multicolumn{6}{|c|}{$\begin{array}{l}\text { 'Percentages are based on respondents using a paid tax preparer to file taxes in } 2003 \text { or } 2004 . \\
\text { 4Averages are computed for respondents who took out an RAL. }\end{array}$}} \\
\hline & & & & & \\
\hline \multicolumn{6}{|c|}{ 'Averages are computed for respondents using a paid tax preparer but not taking out an RAL. } \\
\hline
\end{tabular}

more likely to use a national chain, like $H \& R$ Block or Jackson Hewitt, rather than a local firm or accountant, to file their taxes. Moreover, unbanked households are much more likely to take out a RAL. More than 60 percent of unbanked households using a paid preparer took out a RAL, compared with 30 percent of banked households using paid preparers. These differences persist when controlling for income and employment (results not shown). Unbanked households make up 37 percent of RAL users as a whole. Conditional on filing, banked and unbanked households are equally likely to receive a tax refund. Banked households are 15 percentage points less likely to file for and receive the EITC than unbanked households.
EITC applicants and non-applicants are also likely to have different tax filing experiences. In fact, applying for the EITC is a strong predictor of whether an individual uses a paid tax preparer, whether that tax preparer is likely to be from a national chain, and also whether the individual takes out a RAL. An overwhelming majority of EITC filers, 80 percent, used a paid tax preparer, compared with 58 percent for non-EITC filers. EITC filers using paid preparers are nearly twice as likely to use a national chain as non-EITC taxpayers. Moreover, 56 percent of EITC filers using paid preparers took out a RAL, compared with only 22 percent for non-EITC households using paid preparers. It is possible that their larger 
refunds may encourage EITC filers to take out a RAL, but controlling for the size of the refund, EITC recipients still remain more likely to use a paid tax preparer, and to take out a RAL (results not shown). The cost of tax preparation, with and without RALs, appears to be higher for EITC claimants than other tax filers.

Table 3 lists reasons that individuals cite for taking out RALs. Around 90 percent of RAL recipients state they did so because they wanted the money faster, and most of these correlate highly with the nearly 80 percent of households who said they took out a RAL because they want to pay their bills or other debt faster. That is, they borrowed to pay down other debt. To assess whether this decision is wise, we will need to compare the effective annual percentage rate (APR) of a RAL with the costs incurred by respondents on outstanding debt. Given the high effective APRs of RALs in other studies, it is likely that the costs incurred on outstanding debt would have to be quite high to justify taking out a RAL to pay down such debt.
Interestingly, to the extent that these individuals are paying down debt, they are in effect borrowing money in order to increase net savings. Some 60 percent of households take out a RAL because they want certainty about getting their refund, and another 49 percent say that an important reason for taking out a RAL is to pay the tax preparer.

Individuals without a bank account are somewhat more likely to want the money faster than those with bank accounts. Moreover, unbanked households are 20 percentage points more likely than banked households to state that they used a RAL because they wanted to pay bills or debt faster. This differential potentially reflects other differences other than banked status, including income and asset holdings, which will require further investigation. Unbanked households are also 11 percentage points more likely to take out a RAL in order to pay the tax preparer, than banked households.

Table 4 presents results on how low- and moderate-income households use their refunds. For policy

Table 3

Reasons for Obtaining an RAL by Banked Status' (Standard Errors in Parentheses)

\begin{tabular}{|c|c|c|c|}
\hline Characteristic & All & Banked & Unbanked \\
\hline $\begin{array}{l}\text { Wanted Refund Sooner } \\
\text { Very Important } \\
\text { Somewhat Important } \\
\text { Not at All Important }\end{array}$ & $\begin{array}{l}55 \% \\
32 \\
12\end{array}$ & $\begin{array}{l}54 \% \\
30 \\
16\end{array}$ & $\begin{array}{l}59 \% \\
36 \\
5\end{array}$ \\
\hline $\begin{array}{l}\text { Needed to Pay Tax Prepa } \\
\text { Very Important } \\
\text { Somewhat Important } \\
\text { Not at All Important }\end{array}$ & $\begin{array}{l}20 \% \\
29 \\
51\end{array}$ & $\begin{array}{l}18 \% \\
28 \\
55\end{array}$ & $\begin{array}{l}24 \% \\
31 \\
45\end{array}$ \\
\hline $\begin{array}{l}\text { Wanted to Pay Bills Fast } \\
\text { Very Important } \\
\text { Somewhat Important } \\
\text { Not at All Important }\end{array}$ & $\begin{array}{l}61 \% \\
16 \\
23\end{array}$ & $\begin{array}{l}52 \% \\
18 \\
31\end{array}$ & $\begin{array}{c}78 \% \\
14 \\
9\end{array}$ \\
\hline $\begin{array}{l}\text { Wanted to Be Sure about } \\
\text { Very Important } \\
\text { Somewhat Important } \\
\text { Not at All Important }\end{array}$ & $\begin{array}{l}34 \% \\
26 \\
40\end{array}$ & $\begin{array}{l}28 \% \\
29 \\
43\end{array}$ & $\begin{array}{l}43 \% \\
22 \\
34\end{array}$ \\
\hline Other Reason & $11 \%$ & $9 \%$ & $14 \%$ \\
\hline Sample Size & 155 & 97 & 58 \\
\hline
\end{tabular}

Source: Detroit Area Household Financial Survey.

Notes: Respondents are banked if they responded yes to having a checking account, a savings account, an account with a debit card but no checks, or any other account held at a bank, savings and loan, or credit union. Unbanked respondents responded no to having any of these types of accounts.

'Conditional on receiving a Refund Anticipation Loan (RAL). 
Table 4

Use of Tax Refund by Banked Status and RAL Status

\begin{tabular}{lccccc}
\hline Characteristic & All & Banked & Unbanked & Received RAL & No RAL \\
\hline Received a Refund & $56 \%$ & $60 \%$ & $43 \%$ & $95 \%$ & $48 \%$ \\
Saved All of Refund & & & & & \\
Spent All of Refund & $9 \%$ & $11 \%$ & $5 \%$ & $5 \%$ & $11 \%$ \\
Saved Some/Spent Some & $49 \%$ & $47 \%$ & $53 \%$ & $54 \%$ & $46 \%$ \\
& $42 \%$ & $42 \%$ & $42 \%$ & $40 \%$ & $43 \%$ \\
Spent Refund on: & 2 & & & & \\
$\quad$ Bills or Other Debt & $79 \%$ & $78 \%$ & $81 \%$ & $80 \%$ & $78 \%$ \\
$\quad$ Buy Appliances & 21 & 17 & 35 & 27 & 19 \\
$\quad$ Buy Car & 12 & 11 & 16 & 15 & 11 \\
$\quad$ Pay for Own or & 14 & 14 & 13 & 14 & 14 \\
$\quad$ Children's Education & 38 & 41 & 30 & 36 & 39 \\
$\quad$ Other & 927 & 660 & 267 & 155 & 772 \\
\hline Sample Size & & &
\end{tabular}

Source: Detroit Area Household Financial Survey.

Note: Respondents are banked if they responded yes to having a checking account, a savings account, an account with a debit card but no checks, or any other account held at a bank, savings and loan, or credit union. Unbanked respondents responded no to having any of these types of accounts.

'Conditional on receiving a refund.

${ }^{2}$ Conditional on "spending all" or "spending some and saving some" of the tax refund.

purposes, it is important to assess whether there is a propensity among low- and moderate-income households to save some or all of their refunds. Tax refunds, given the size of the lump sum relative to annual income, could play an important role in most low- and moderate-income households' lives. Around 80 percent of tax filers, and 56 percent of our sample of low- and moderate-income households, received a tax refund, and the average refund of those receiving one was $\$ 1,866$. More than 50 percent of low- and moderate-income individuals who received a tax refund indicated that they saved all ( 9 percent) or a part ( 42 percent) of their tax refund. Almost one-half of those receiving tax refunds spent the entirety of their refunds. Among those who spent some or all of their refund (9l percent), nearly 80 percent used their refund to pay down bills or other debt. That is, even among the group that spent some or all of their refund, most households indicated that they used the spending to increase net savings by reducing indebtedness (for related work, see Shapiro and Slemrod, 1995).

The lump-sum nature of tax refunds may also make it useful for large asset purchases in the face of liquidity constraints or difficulties constraining consumption to save up for such purchases. Twenty-one percent of respondents used their refund to buy appliances and another 12 percent used the refund to buy a car. Another 14 percent of respondents used the refund to pay for their own education or their children's education, an important investment in human capital.

The propensity to save some or all of their tax refunds is high among both banked and unbanked individuals. While unbanked households are only one-half as likely to save all of their tax refund. 47 percent of unbanked households saved at least some of their refund, not too far behind the 53 percent rate for banked households. For both groups, the patterns of spending their refunds were roughly similar. That is, among the 90 percent to 95 percent of households who spent some or all of their refund, nearly 80 percent of both banked and unbanked households stated that they used their refund to pay down bills or other debt. Unbanked households were nearly twice as likely as banked households to say they spent their refund to buy appliances ( 35 percent compared to 17 percent).

Tax refund savings plans may be a way for both of these types of households to save, especially given the difficulty these families have saving during the course of the year. Low- and moderateincome households are not likely to save during the course of the year. Among our sample members, nearly one-third do not have any savings and an additional 20 percent did not contribute to their 
savings at all during the year prior to the survey. Taken together, about three-quarters of the sample is not able to save on a regular basis (savings results not shown).

Table 4 also shows how households who do and do not receive RALs spend or save their tax refunds. RAL users are less than one-half as likely as nonRAL users to save the entirety of their refunds, but 5 percent of them still save all of it, and 40 percent of RAL users save some of their refund, quite close to the 43 percent of non-RAL takers who save some of their refund. RAL takers are 8 percentage points more likely to spend all of their refunds than nonRAL users ( 54 percent compared with 46 percent). Among those who spent some or all of their refund, both RAL users and non-RAL users had similar spending patterns. About 80 percent of both groups spent some of their refund to pay down bills or other debt. RAL takers were 13 percentage points more likely to purchase a durable good, such as an appliance or a car. Given few differences in the use of the refund between RAL takers and non-takers, however, it appears that the receipt of a RAL is not well correlated with how individuals spend the money. That is, households who wait for their tax refunds spend in similar ways from those who do not wait. As discussed earlier, we will explore in future work whether the decision to use a RAL to pay down other debt is economically justified, in part by comparing effective APRs on RALs to plausible ranges of APRs and other costs on outstanding other debt.

\section{CONCLUSIONS AND POLICY IMPLICATIONS}

The key findings of this paper are threefold. First, many low- and moderate-income households are connected to the tax system. Seventy percent of the individuals in our sample filed a tax return, and 80 percent of those filing received a tax refund. This finding suggests that the tax system is critical to the financial lives of low-income households and may serve as a vehicle to integrate low- and moderateincome households into the financial mainstream.

Second, many low- and moderate-income households use a paid preparer and take out RALs, often at a high cost. Given the societal goal of rewarding work and redistributing income to lower-income households, optimal income redistribution policy would suggest that policy makers focus on ways to reduce the transaction costs associated with tax filing for low- and moderate-income households. Such steps could include measures to reduce tax complexity for low- and moderate-income filers (see, e.g., Holtzblatt and McCubbin, 2004; Barr, 2004; and President's Advisory Panel on Federal Tax Reform, 2005). In addition, there are a series of measures that could be undertaken to bring lowincome households into the banking system (Barr, 2004). Banked households would face lower incentives to take out RALs because their refunds could be direct deposited more quickly than receiving a paper check, they would likely face fewer liquidity constraints, and they would face lower costs for converting the income into usable form because they would not need to cash the government refund check. Thus, policy initiatives to bring low-income households into the banking system, such as a tax credit provided to financial institutions for providing low-cost, electronically-based bank accounts to low-income households, would likely contribute to optimal income redistribution policy (Barr, 2004).

Third, the tax filing process may provide an opportunity to encourage savings. Our findings suggest that low-and moderate-income households may find savings plans that are tied to tax refunds (Duflo et al., 2005) attractive, although our data may suggest that savings plans that are not focused solely on retirement may be more desirable for many of these households. Despite the fact that most households in our study are not able to save regularly during the course of the year, and hold few assets, many respondents save some or part of their refund, and those who spend it often use the refund to pay bills or other debt, thereby increasing net savings. A sizeable group of respondents also use the tax refund for lump-sum purchases, such as appliances and automobiles. This provisional data is suggestive that individuals may use the withholding system as a means of short-term saving and as a precommitment device against over-consumption, although alternative explanations based on uncertainty regarding tax liability are highly plausible. We test these hypotheses using attitudinal and other data from our survey in subsequent work.

\section{Notes}

We would like to thank our project manager, Esther Ullman, our production manager, Sara Freeland, Terry Adams, the team at the Survey Research Center, and our Advisory Board, who worked together on sampling, survey design and data collection. We are grateful to Chester Choi, Maria Dooner, and Robyn Konkel for research assistance. The study received 
generous support from the Ford Foundation, Fannie Mae Foundation, Mott Foundation, MacArthur Foundation, Annie E. Casey Foundation, and Community Foundation of Southeastern Michigan, as well as the National Poverty Center, Center on Local, State and Urban Policy, Provost, Vice President for Research, and Law School of the University of Michigan.

1 With sampling weights, our sample represents the population of Detroit metropolitan area residents living in low-, moderate-, and middle-income census tracts.

2 During survey development, respondents were not able to distinguish separately the amount that they paid to tax preparers for tax preparation as distinct from the cost of RALs so the final questionnaire asks about combined costs. We report the total cost for tax preparation and RALs, and will later impute separate costs.

\section{References}

Aizcorbe, Ana M., Arthur B. Kennickell, and Kevin B. Moore. Recent Changes in U.S. Family Finances: Evidence from the 1998 and 2001 Survey of Consumer Finances. Federal Reserve Bulletin (January 2003): 1-32.

Barr, Michael S. Banking the Poor. Yale Journal on Regulation 21 (Winter 2004): 121-238.

Bertrand, Marianne, Sendhil Mullainathan, and Eldar Shafir. A Behavioral-Economics View of Poverty. American Economic Review Papers and Proceedings 94 (May 2005): 419-423.

Berube, Alan, Anne Kim, Benjamin Forman, and Megan Burns. The Price of Paying Taxes: How Tax Preparation and Refund Loan Fees Erode the Benefits of the EITC. The Brookings Institution and the Progressive Policy Institute, Washington, D.C., 2002.

Duflo, Esther. Poor But Rational? In Abhijit Banerjee, Roland Benabou, Dilip Mookherjee, eds. What Have We Learnt About Poverty? Oxford: Oxford University Press, 2004.

Duflo, Esther, William G. Gale, Jeffrey Liebman, Peter Orszag, and Emmanuel Saez. Saving Incentives for Low- and Middle-Income Families: Evidence from a Field Experiment with H\&R Block. Cambridge,
MA: National Bureau of Economic Research, 2005. NBER Working Paper 11680.

Dunham, Constance. The Role of Banks and Nonbanks in Serving Low- and Moderate-Income Communities. U.S. Department of the Treasury, Office of the Comptroller of the Currency. Mimeo, Washington, D.C., 2001.

Eissa, Nada and Jeffrey Liebman. Labor Supply Response to the Earned Income Tax Credit. Cambridge, MA: National Bureau of Economic Research, 1995. NBER Working Paper 5158.

Holtzblatt, Janet and Janet McCubbin. Issues Affecting Low-Income Filers. In Henry Aaron and Joel Slemrod, eds. The Crisis in Tax Administration. Washington D.C.: Brookings Institution Press, 2004, pp. 148-188.

President's Advisory Panel on Federal Tax Reform. Simple, Fair, and Pro-Growth: Proposals to Fix America's Tax System. Washington, D.C., 2005.

Rhine, Sherrie. The Earned Income Tax Credit Program: Using the EITC as a Tool for Banking the Unbanked and Promoting Saving. Federal Reserve Bank of New York, New York, 2005.

Seidman, Ellen, Moez Hababou, and Jennifer Kramer. A Financial Services Survey of Low- and ModerateIncome Households. Center for Financial Services Innovation, Chicago, 2005.

Shapiro, Matthew and Joel Slemrod. Consumer Response to the Timing of Income: Evidence from a Change in Tax Withholding. American Economic Review 85 (March 1995): 274-283.

Souleles, Nicholas. The Response of Household Consumption to Income Tax Refunds. American Economic Review 89 (September 1999): 947-958.

Thaler, Richard. Anomalies: Saving, Fungibility, and Mental Accounts. Journal of Economic Perspectives 4 (Winter 1990): 193-205.

Thaler, Richard and George Loewenstein. Intertemporal Choice. Journal of Economic Perspectives 3 (Fall 1989): 181-193.

Tufano, Peter, Daniel Schneider, and Sondra Beverly. Leveraging Tax Refunds to Encourage Savings. Washington, D.C.: Retirement Security Project, 2005. Policy Brief 2005-8. 